\title{
Más allá del dolor...
}

\author{
Eugenia Calquin Morales \\ Colectivo editorial Mapuexpress \\ y Grupo de Trabajo por los Derechos Colectivos
}

¿Cuánta sangre mapuche derramada sobre la tierra equivale a tan solo un puñado de cenizas de la usurpación? ¿Cuántas madres más deberán llorar la muerte de los hijos que decidieron recuperar un poco de todo lo robado? ¿Cuántos niños de la tierra deberán cambiar sus juegos por estrategias de autodefensa cuando vengan los operativos policiales a destruirles la infancia? ¿Cuántas mujeres mapuche golpeadas necesita Usted para decir basta? ¿Cuántos presos más? ¿Cuánto más?

Nuestra gente ha debido elegir entre vivir prisionera tras las rejas, a vivir la prisión de ver crecer a sus hijos entre las plantaciones de pinos y eucaliptus, esas que nada dejan brotar en las pocas hectáreas de libertad que nos van quedando; esas que se llevan hasta la última gota de agua que corre escondida en las profundidades de la tierra; esas que nos dejan sin medicina y que apagan poco a poco los colores de nuestros tejidos... Esas plantaciones de ambición privada subsidiada por el Fisco...

Ni el ayuno de nuestros presos en las cárceles, ni las huellas en nuestros cuerpos, ni las cicatrices en nuestros rostros, ni menos las que llevamos escondidas en el alma, han podido con la indolencia chilena ni menos con la codicia extranjera.

Pero alguna vez escuché a una ñaña decir que así como existe el día también existe la noche y que si existe lo bueno también lo malo, debemos estar seguros de que pronto ha de llegar la justicia haciendo el equilibrio con lo que hace siglos venimos viviendo...

Mientras tanto más jóvenes seguirán levantándose y seguirán los ancianos alentándoles con la sabiduría de sus palabras 
portadoras de conocimiento ancestral...

Hay tanta belleza en la determinación de luchar que tiene nuestra gente, hay tanta ternura en nuestra fuerza... Somos gente de la tierra, por ella somos lo que somos, a ella ofrendamos lo que hacemos y duélale a quien le duela, mientras su fuerza respire en nosotros, nosotros seguiremos de pie... 